\title{
Elaboració de seqüències didàctiques. Les aplicacions de la Física i la Química en la Meteorologia
}

\author{
Dolors Vidal i Segarra \\ IES Manuel Sales i Ferré, Ulldecona \\ mvidal5@xtec.cat
}

L'elaboració de seqüències didàctiques ens permet assolir un doble objectiu: l'autoformació del professorat (individualment o en grup) i l'aplicació de nous mètodes d'ensenyament de les ciències innovadors. Tot plegat amb la finalitat d'afavorir l'interès general envers les Ciències de la Naturalesa.

\section{Introducció}

Als mitjans de comunicació sovintegen notícies que mostren una preocupació prou estesa actualment en la societat, preocupació que el professorat comparteix majoritàriament, referida als resultats acadèmics del nostre alumnat de Ciències. Què podem fer nosaltres per incidir en el sistema d'ensenyament i minimitzar aquests problemes des de la nostra tasca diària?

El jovent d'avui viu immers en un món on els mitjans audiovisuals són una constant en les seves activitats. Per això és fàcil fer-nos càrrec que dedique el seu temps preferentment a aquesta mena d'activitats (Internet, videojocs, telèfons mòbils, xat, TV, MP4...) i no tant a l'estudi, com nosaltres desitjaríem.

Tenim davant, doncs, un repte ben difícil: aconseguir motivar el nostre alumnat perquè les activitats relacionades amb l'estudi de les ciències li resulten més atractives.

Hem d'adaptar les estratègies d'ensenyament a les noves realitats socials per tal que resulten més engrescadores. Aconseguir que l'alumnat comprenga que necessitarà les ciències per a entendre els avenços (i els límits) científics i tecnològics que li permeten gaudir dels enginys anteriors, de forma crítica, ètica i sostenible. En definitiva, per saber desenvolupar-se com a ciutadans o ciutadanes lliures en la societat.

És cert que les mancances a nivell de continguts en l'alumnat tenen una rellevància important, però també ens hem de plantejar com contribueix la nostra forma d'ensenyar (basada tradicionalment en la transmissió de conceptes) en els resultats acadèmics. Val a dir que com a professorat fem el que podem, que no sempre és el que voldríem, pels molts condicionaments que afecten la nostra tasca docent i que ara no és el moment de comentar. Així que ens centrarem en com optimitzar els resultats de la nostra feina, tot presentant-la en formats més atractius per a l'alumnat.

Tant dins com fora de l'estat espanyol actualment hi ha diversos grups de treball que investiguen mètodes innovadors d'ensenyament de les ciències. Els grups apunten, amb diferents matisos, la conveniència de dissenyar seqüències didàctiques per a afavorir un aprenentatge significatiu del nostre alumnat en ciències. Destaquem, de forma resumida, els punts de coincidència que proposen els diferents grups:

- La importància de contextualitzar la ciència que s'ensenya, de relacionar-la amb problemes rellevants de l'entorn immediat de l'alumnat.

- La necessitat de seqüenciar les activitats d'ensenyament-aprenentatge en un cert ordre.

- S'ha de donar molta importància als processos de comunicació que s'estableixen a l'aula.

- És important incloure l'avaluació-regulació en tot el procés d'ensenyament-aprenentatge i replantejar el paper de l'error.

- Considerar que tota seqüència didàctica ha d'afavorir l'ús de les NTIC (Noves Tecnologies de la Informació i de la Comunicació).

En definitiva, la recerca d'aquests grups segueix una filosofia comuna: contextualitzar la ciència, fer- 
la més propera al context quotidià de l'alumnat, ensenyar una ciència que permeti la discussió i la reflexió entre iguals.

Amb l'estratègia d'elaborar seqüències didàctiques per part del professorat es potencia la introducció de noves formes d'ensenyament amb activitats CTSA (Ciència, Tecnologia, Societat i Medi Ambient). Aquestes activitats han de resultar atractives $\mathrm{i}$ interessants per a l'alumnat. Hem de situar l'alumnat davant situacions-problema en un context determinat que hauran d'intentar resoldre, en la mesura de les seues possibilitats, tot aplicant els coneixements de les diferents matèries adquirits al llarg de l'ESO.

Aquest procés ha de facilitar l'alumnat l'adquisició de les competències en l'ús del seu coneixement científic. Això contribuirà al seu desenvolupament personal, i farà l'alumnat més capaç de deliberar, d'analitzar i d'argumentar de forma crítica i raonada la realitat que viu cada dia.

La funció del professorat que elabora les seqüències és aconseguir la implicació de l'alumnat en la seva alfabetització científica.

\section{Què són les seqüències didàctiques?}

El terme "seqüència didàctica" és el terme amb el que a Catalunya ens referim a les unitats didàctiques d'extensió més curta, d'unes sis hores de durada (pot ser més, o menys). Vàries seqüències didàctiques d'aquesta extensió relacionades pel contingut, poden servir per a configurar una unitat didàctica (de deu, de vint hores...).

El curs 2005-06 vaig gaudir d'una llicència d'estudis concedida pel Departament d'Educació per dur a terme (amb Juli Tena com a coautor) l'elaboració de seqüències didàctiques per treballar els continguts de Física i Química de l'ESO en el context de la Meteorologia.

Des del principi la idea era seqüenciar les activitats entorn dels següents blocs:

1. La Química de l'aire (seqüència que havíem elaborat abans de fer aquesta llicència, en el marc del Programa de Formació en Ciències a I'ESO, PFECE).

2. Estudiem les forces, el moviment i l'energia en Meteorologia.

3. Treballem les ones, l'electricitat i el magnetisme en Meteorologia.

4. Implicacions de la Meteorologia en la Societat.

Tant la seqüència de "La Química de l'aire", com d'altres seqüències elaborades pels grups de tre- ball del PFECE, així com el material que anàvem fent durant els dos primers trimestres de llicència, van ser consultats i experimentats en part pel professorat en cursos de formació sobre l'elaboració de seqüències didàctiques, i també per companys $i$ companyes propers a nosaltres i, fins i tot, en alguna ocasió, pel mateix l'alumnat. La impressió i l'opinió era que les seqüències requerien moltes hores lectives per poder-les aplicar tal i com les presentàvem.

La il.lusió amb la que comença el disseny de les seqüències didàctiques engresca tant en la recerca de les activitats que s'hi proposen, que és fàcil caure en fer un material massa extens. És per això que s'han de fer contínuament nous replantejaments per aconseguir un material realment aplicable. A nosaltres també ens va passar, de fer molt de material; així que juntament amb la tutora que ens ha orientat en l'elaboració d'aquest treball, la professora Neus Sanmartí, del ICE de la UAB, vàrem decidir replantejar la presentació final del material.

De manera que, per un costat, vam ordenar el material que havíem fet fins aleshores en "mòduls" de curta durada que treballen un contingut més específic, com després concretarem. Aquests mòduls contenen activitats que poden constituir (sense haver de fer gaires modificacions) una seqüència didàctica. Apareixen tots junts en l'annex d'aquesta llicència i els considerem un banc d'activitats força interessants, ja que hi trobareu moltes activitats que es poden adaptar fàcilment per a dissenyar material d'atenció a la diversitat, per aplicar-hi les noves tecnologies (Interactive Physics), per aplicar els conceptes de caire més teòrics treballats a classe...

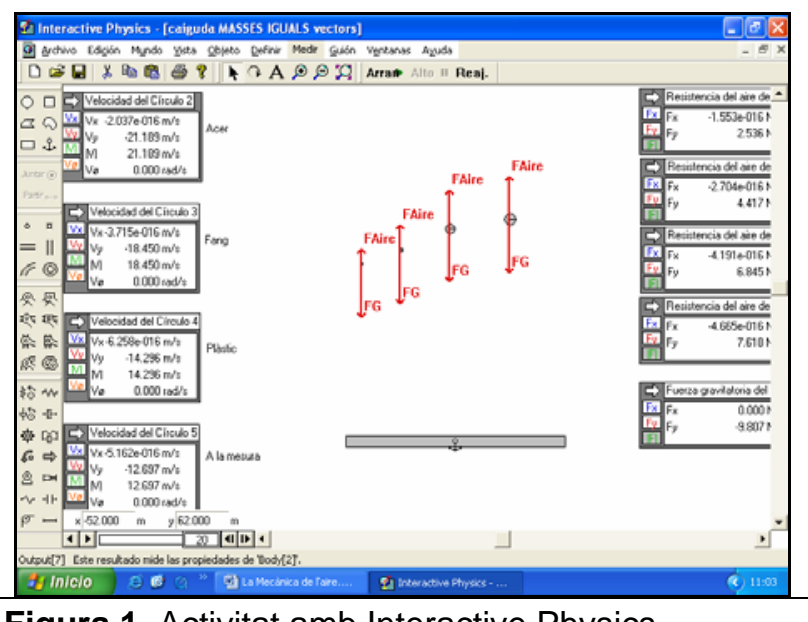

Figura 1. Activitat amb Interactive Physics.

Per exemple, la fig. 1 mostra una activitat que vam dissenyar amb el programa Interactive Physics per simular com cauen diferents objectes a l'aire 
(per poder utilitzar les diferents pràctiques que presentem amb aquest programa, l'haureu de tenir carregat a l'ordinador).

Per altra banda, durant el tercer trimestre vam dissenyar dues seqüències didàctiques curtes (de sis a vuit hores de durada) que us poden servir de model per a elaborar-ne d'altres. El títol de les dos seqüències és:

- "Què hi ha aquí?", seqüència (fig. 2) que treballa les unitats de mesura a partir de la construcció casolana dels instruments de mesura d'una caseta meteorològica i de la construcció de la pròpia caseta meteorològica. Està adreçada preferentment a l'alumnat de segon d'ESO, i

- “Ei, que anem d'excursió!", seqüència per a treballar els gràfics a partir dels gràfics que representen les variables meteorològiques de l'Edumet (http://www.xtec.cat/edumet/).

Està adreçada (preferentment) a l'alumnat de quart d'ESO. En ambdós casos es poden readaptar els continguts en funció del tipus d'alumnat al qual van dirigides.

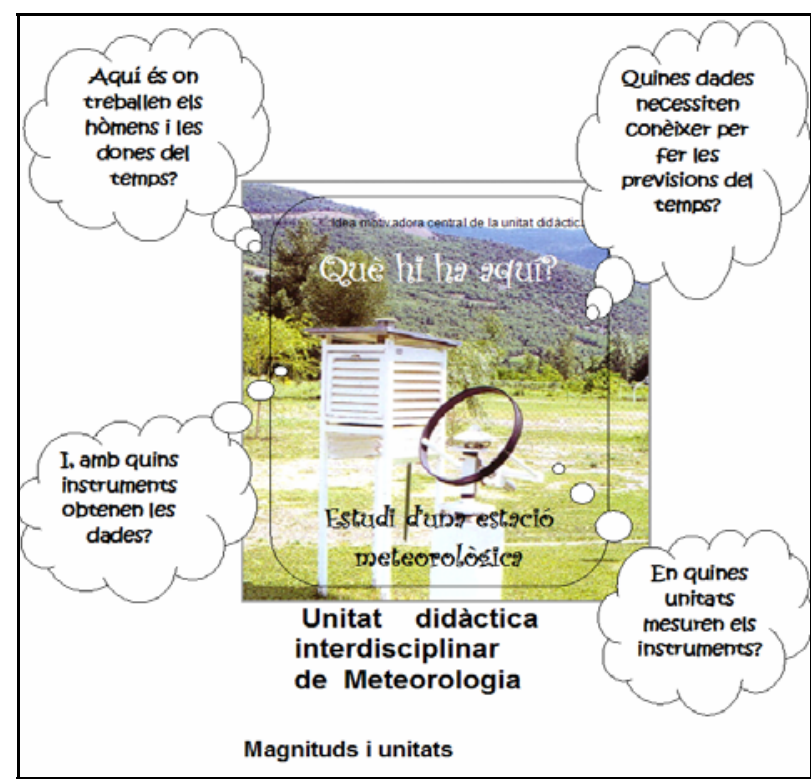

Figura 2. Coberta de la seqüència didàctica "Què hi ha aquí?".

\section{Metodologia emprada}

Volem distingir dues etapes en la metodologia emprada al llarg de la llicència d'estudis, a tall d'orientació.

En la primera etapa del treball, duta a terme els dos primers trimestres del curs 05-06, podem diferenciar tres fases.
- Una primera fase de recerca d'activitats CTSA (en la bibliografia i en Internet) i recerca de les idees prèvies de l'alumnat sobre els conceptes físics que preteníem treballar per a estudiar els continguts de Física de la ESO contextualitzats amb els fenòmens meteorològics més quotidians. Malgrat haver arribat a tenir un banc d'activitats considerable, aquesta etapa no es va acabar mai perquè, en les successives modificacions fetes al llarg de treball, sempre hi ha hagut detalls per canviar que requerien noves consultes per trobar activitats més idònies.

- En la segona fase, vam procedir a l'estructuració dels continguts i dels apartats que definitivament constituirien el material. Aquest procés va requerir l'anàlisi de les activitats, la valoració dels avantatges, de les dificultats de la seva aplicació... En definitiva, estudiar la seva idoneïtat.

- Finalment, la tercera fase d'aquesta etapa consistiria en l'adaptació de les activitats seleccionades al format del text del material elaborat que presentem en l'Annex com a mòduls. En aquelles activitats que hem considerat menys conegudes hem afegit les orientacions per al professorat per facilitar-ne la seva aplicació. (Per cert, eviteu fer servir moltes taules, quadres de text $o$ altres detalls en el disseny de les pàgines, perquè és possible que després us donen problemes a l'hora canviar el disseny de la pàgina).

A partir del tercer trimestre, aproximadament, podem considerar que va començar la segona etapa del treball, en la que vam elaborar els dos models de seqüència didàctica més curta citats anteriorment, amb el corresponent Quadern de l'alumnat i el Quadern del professorat, i les orientacions que faciliten la seva l'aplicació a l'aula.

Per no allargar massa l'extensió d'aquestes notes us oferim una presentació en Power Point (secció Suplement d'aquest número) (per al professorat que presenta, de forma resumida, els passos més generals que podem seguir en el procés d'elaboració de seqüències. Altres seqüències didàctiques les podeu trobar a la pàgina del CDECT: http://www.xtec.cat/cdec/actuals/pagines/pfece2.ht m\#Seqüències didàctiques del PFECE, amb els títols:

1. Éssers vius: els bacteris i els virus

2. Minerals i roques

3. La Terra: atmosfera, aigua i escorça terrestre 
4. El moviment: construcció i interpretació de gràfiques

5. Biologia i esport: les funcions de relació en un context CTS

6. Seguint la pista a l'ADN

7. El camí de l'energia: els aliments

8. L'electromagnetisme

9. La llum i el color. Química de l'atmosfera

10. Productes químics de la vida quotidiana: la química de la neteja

11. Productes químics de la vida quotidiana: la farmaciola

12. Éssers vius: els bacteris i els virus

\section{Quins aspectes hem de considerar en el disseny de les seqüències didàctiques?}

El primer pas de l'elaboració de seqüències és decidir el concepte (o conceptes) que serà objecte d'estudi, tot relacionant-lo amb un context quotidià perquè motive majoritàriament l'alumnat. Després s'han de seleccionar i de seqüenciar les activitats que es treballaran en la seqüència, seguint (per exemple) la metodologia que a continuació expliquem.

En l'elaboració de les seqüències hi ha diversos aspectes que hem de considerar en funció dels objectius que ens marquem, com ara:

- Concretar el model teòric que volem treballar

- Explicitar la rellevància que pot tenir el seu estudi per a l'alumnat

- Contextualitzar els continguts amb un tema amb enfocament CTSA que puga interessar l'alumnat

- Organitzar i seqüenciar els continguts que es pensen treballar, atenent el seu grau de complexitat i d'abstracció

Pel que fa a les activitats, haurem de seleccionar-les en funció del seu objectiu didàctic:

- Per explorar les idees prèvies, per plantejar la situació o el problema objecte d'estudi i per a compartir els objectius d'aprenentatge

- Per a construir nous conceptes, procediments o valors que possibiliten donar resposta al problema i per a regular les dificultats (i errades) de l'alumnat que apareixen en el procés

- Per abstreure i sintetitzar les idees i els procediments apresos, tot relacionant-los amb d'altres ja coneguts

- Per aplicar (transferir) les noves idees i avaluar si s'han après els nous coneixements
Hem de distribuir les activitats en un cert ordre en el temps:

- De les més senzilles a les més complexes

- De les més concretes a les més abstractes (per aconseguir que l'alumnat que es perd, ho faça el més tard possible)

- Activitats per a afavorir la reestructuració de les idees prèvies (les activitats d'exploració no són quelcom per fer a l'inici i no tornar-les a tenir més en compte)

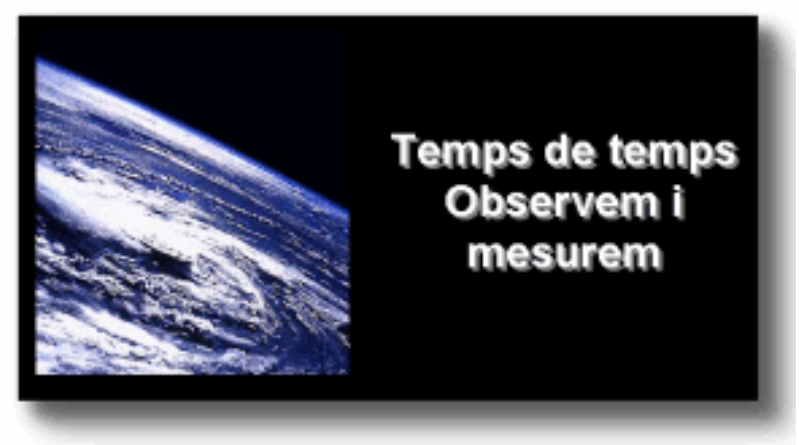

Figura 3. Activitat interactiva del JClic (http://clic.xtec.net/db/act ca.jsp?id=2022)

- Plantejant cada activitat per a promoure l'avaluació-regulació de les idees i de les formes de fer (els errors s'han de regular en el mateix moment que es manifesten i no al final, quan ja no hi ha remei).

Hem de diversificar les activitats d'aprenentatge per evitar caure en rutines. Poden ser activitats com ara:

- Observació i recollida de dades, classificació, ordenació, jerarquització...

- Realització d'experiments, de petites investigacions...

- Construcció o interpretació de maquetes, models analògics, simulacions...

- Resolució de WQ, MUDs, caceres de tresors, JClic, etc.

- Anàlisi de textos provinents de diaris, revistes, Internet...

- Redacció de textos i anàlisi de la seva idoneïtat

- Passi d'audiovisuals: Vídeos, pel-lícules, TV, CDs...

- Resolució de problemes oberts

- Debats amb posicions contraposades, jocs de rol...

- Ús d'instruments variats: mapes conceptuals, V de Gowin, esquemes, bases d'orientació o cartes de navegació... 
- Realització de treballs monogràfics sobre temes d'aplicació escollits per l'alumnat, conferències fetes per l'alumnat, presentacions en Power Point, realització de fotografies, vídeos...

La gestió de l'aula ha de ser suficientment flexible per poder adaptar les activitats a les necessitats de l'alumnat individualment i del grup-classe en el seu conjunt, amb la finalitat d'optimitzar el temps. Per tant, hem de facilitar ocasions per a:

- Potenciar la comunicació d'idees

- Expressar-les oralment i per escrit

- Regular les possibles desviacions respecte de la visió científicament vàlida

- Enfortir la comunicació entre companys i companyes: fomentar el treball en parella, en grups, de tota la classe, sempre des d'un punt de vista de cooperació.

Finalment, en l'aplicació a l'aula de les seqüències didàctiques distingim tres fases, que especifiquem amb més detall al PPT (secció Suplement d'aquest número) que complementa aquest article:

- Fase inicial o prèvia: Presentació global de la seqüència didàctica (en el PPT la identifiquem com a Unitat Didàctica, UD, per ser una definició més emprada usualment).

- Fase central: Introducció i construcció dels nous coneixements.

- Fase final: Aplicació i generalització.

Hem de seleccionar els tipus d'activitats més adients per a cada punt de la UD que dissenyem, en funció dels objectius específics de cada fase. En trobareu exemples en el PPT.

\section{Quin material podeu trobar en aquesta llicència d'estudis?}

El material final de la llicència d'estudis el podeu trobar amb el cercador de llicències d'estudis de la pàgina del $X T E C$ :

http://www.xtec.es/formacio/llicencies/index.htm.

És un material que nosaltres considerem com a punt de partida i no definitiu, ja que l'hem de seguir revisant, canviant i esmenant.

El banc d'activitats que s'ofereix en els mòduls presentats a l'Annex, ens permet una consulta ràpida i per conceptes (força, pressió, moviment, energia, ones...). Hi podreu seleccionar activitats pràctiques senzilles $i$ interessants sense necessitat d'haver de navegar a través d'Internet (amb la despesa de temps tan considerable que això implica).
Com a exemple, com fer aquest model d'ona (fig. 4).

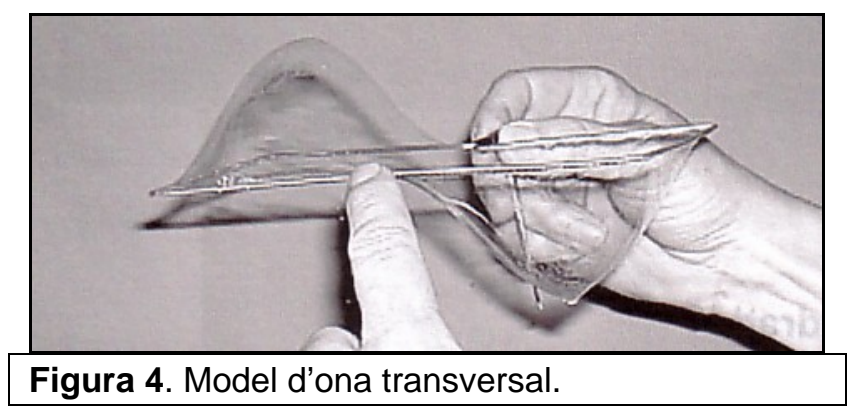

$\mathrm{Hi}$ ha activitats ja conegudes pel professorat $\mathrm{i}$ que ens resultaran familiars. Però encara que pensem que l'alumnat les coneix, no sempre és així. De manera que paga la pena intentar trobar el moment adequat per a explicar-les a classe.

Altres activitats ens són desconegudes al professorat perquè no ens han arribat a les mans. Així que us recomanem fer una primera ullada a aquests mòduls de l'Annex per veure el recull d'activitats, que és gran. Potser així ens ve la idea per a una nova seqüència que pot ser de Meteorologia o d'un altre context interessant, proper i útil al nostre alumnat.

En aquest Annex de la llicència, hi trobareu onze mòduls que s'agrupen en les següents carpetes:

\section{Carpeta 1. Forces i pressió}

1. Com és l'aire?

2. La força de l'aire que ens envolta

3. Vivim immersos en un mar d'aire

4. La pressió atmosfèrica varia amb l'altura. El buit

5. L'empenyiment de l'aire

6. Mesura de la pressió atmosfèrica

\section{Carpeta 2. El moviment}

1. El moviment de les masses d'aire

2. Pluja o vent? Fred o calor?

3. Fenòmens que produeix el moviment de l'aire

\section{Carpeta 3. L'energia}

1. Energia, calor, temperatura. Són sinònims o conceptes diferents?

2. Una energia mil.lenària

I a les tres carpetes següents agrupem les activitats que poden servir com a base i com a orientació per a dissenyar seqüències que treballen els 
conceptes d'ones, d'electricitat i de magnetisme a partir de fenòmens meteorològics, així com les implicacions de la Meteorologia en la societat:

\section{Carpeta 4. Treballem les ones (orientacions)}

\section{Carpeta 5. Treballem l'electricitat i el magnetisme (orientacions)}

\section{Carpeta 6. Implicacions de la Meteorologia en la Societat (orientacions)}

Les activitats que hi proposem es poden agrupar en una seqüència (que seria més adient per a l'àrea de socials) o afegir-ne només alguna en seqüències que treballen la resta de mòduls.

\section{CONCLUSIONS}

\section{Suggeriments}

Trobareu moltes pàgines relacionades amb la Meteorologia a Internet. Sembla que estigui tot fet $\mathrm{i}$ poca cosa més puguem dir-hi. Però nosaltres, com a professorat, podem treballar aquests materials tan fabulosos que ens ofereix la xarxa des d'un punt de vista un xic diferent. Podem aprofitar-nos de l'interès que la Meteorologia desperta en l'alumnat per a estudiar aquells conceptes de Física i Química que en una explicació convencional, sense context, se'ls fan avorrits.

Podem treballar les magnituds i les unitats; fer un tractament acurat de gràfics que representen les variables meteorològiques; usar els instruments de mesura de la caseta meteorològica, confeccionarne models senzills (com el de la fig. 5), introduir conceptes com ara força, pressió, temperatura, energia, càrregues, ones; estudiar les implicacions de la Meteorologia en la societat... Aquesta extensió obliga a triar un motiu d'estudi concret, per no perdre'ns.

A l'hora de començar el disseny d'una seqüència didàctica, i a mode de resum, us suggerim no triar un tema molt general perquè serà més difícil aconseguir una seqüència curta que es puga aplicar a l'aula. Triar un objectiu d'aprenentatge que motive l'alumnat, que li siga proper i interessant, que tinga un nivell adequat per a les seves característiques, que permeta el tractament de la diversitat i que facilite la regulació de les errades i la possibilitat d'aprendre'n d'aquestes.

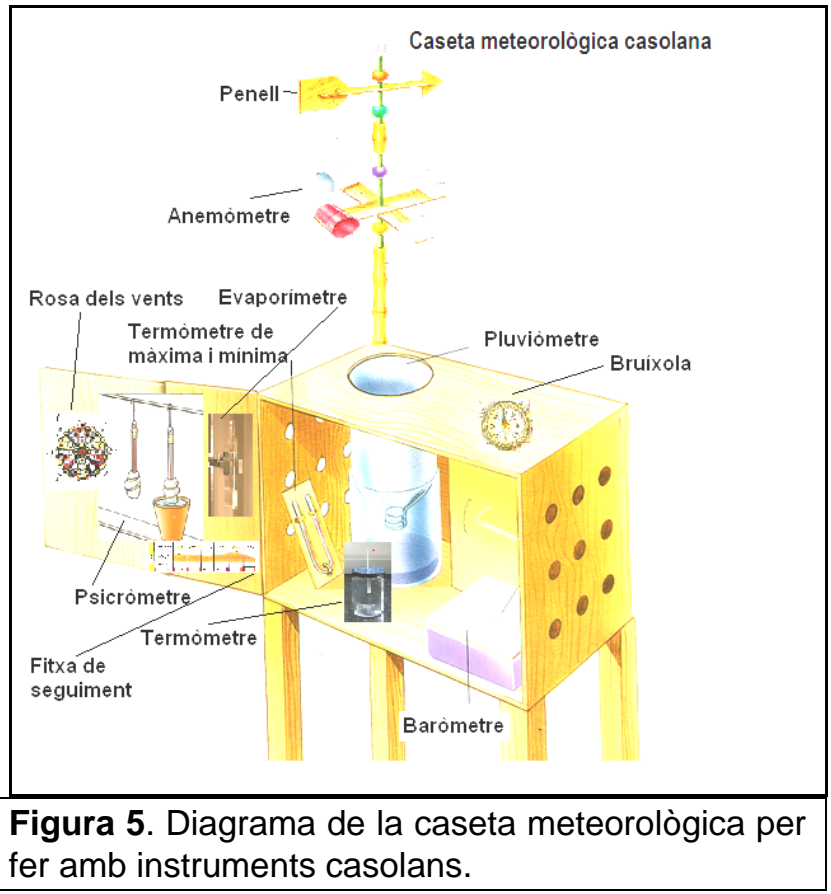

\section{Aplicacions}

Des de fa molts anys hem impartit en moltes ocasions crèdits variables de Meteorologia des d'un punt de vista més estàndard, no tant des de la filosofia de les seqüències didàctiques, que llavors desconeixíem. Malgrat que la Meteorologia, per la nostra experiència, és un tema massa extens, que ens ha obligat a centrar-nos en altres conceptes més concrets, ens ha deixat molt clar que aquest és un tema que atreu en general l'alumnat $i$ té bon resultat en la seva aplicació.

\section{Valoracions}

Si bé el nostre treball ha acabat tenint una forma diferent de la que pensàvem en un principi, el procediment que hem seguit i les dificultats amb què ens hem trobat poden servir com a exemple del procés d'elaboració de seqüències didàctiques per al professorat interessat a provar de fer-ne.

No és un procés estàndard o tancat. Ens hem d'anar adaptant al material que va sortint per poder cobrir finalment els aspectes més generals que volem treballar en la seqüència didàctica. Nosaltres hem fet això. Per tant, considereu aquest material $\mathrm{i}$ aquesta forma de fer totalment oberts a les modificacions que tant l'alumnat com el professorat considerem oportunes.

Hem de dir també que, si bé us pot semblar un procés llarg i dificultós, si es tria un motiu per treballar "petit" (creiem que com més petit millor), po- 
drem gaudir més en la seva elaboració i evitarem patiments i angoixes. L'elaboració de petites seqüències, de molt poques hores que segueixen l'estructura que hem anat proposant al llarg del nostre treball ens pot servir d'incentiu en la nostra tasca docent.

Tot plegat no és una tasca gaire fàcil i en ocasions no rep el reconeixement social que es mereix. Així que hem d'intentar trobar cadascú i cadascuna de nosaltres activitats que ens facin sentir més bé. Amb la realització de petites seqüències didàctiques, unes continuació de les altres, ho podem aconseguir.

No es tracta de proposar-nos grans fites (que ens poden fer desistir a mig camí), sinó d'anar fentne cada curs una (o més) de petita fita. En pocs anys (i el temps corre molt ràpid), tindrem una petita collecció de la que estarem més que pagats $i$ pagades... A més a més, pensem que com cada cop tenim menys crèdits variables i que com la nostra tasca està condicionada a cobrir el currículum, les ocasions d'introduir aquest tipus d'activitats a les classes seran limitades. Per tant, si són més curtes, ho tindrem més fàcil.

A tall d'exemple us comento que en un taller realitzat a Tortosa aquest curs sobre l'elaboració de material de ciències per a l'alumnat nouvingut que no entén el català, entre tot el professorat del taller vam dissenyar unes vint unitats d'una, dues o poc més hores que, reunides en un dossier, ens serveixen de material de gran utilitat per a atendre l'alumnat nouvingut amb nivells diferents. Tanmateix en un altre seminari realitzat a Reus el curs passat el professorat va dissenyar (partint d'algunes activitats que solien fer a classe) unes petites unitats didàctiques força interessants i fàcils d'aplicar a l'aula, ja que es poden integrar al temari de ciències sense grans dificultats.

És evident que hi ha professorat que es mou i no es conforma amb seguir exclusivament les indicacions dels llibres de text (que són força bons, per cert). Considerant l'esforç personal que suposa l'elaboració de materials innovadors, seria d'agrair que aquesta tasca silenciosa $\mathrm{i}$ íntima que realitza el professorat pogués sortir a la llum (l'EDU365 és la plataforma perfecta per a fer-lo) i que fos reconeguda des de l'administració com un mèrit en la nostra formació permanent.

Per fer boca, us animem a començar a treballar en l'àmbit de les seqüències didàctiques fent una ullada a alguna de les seqüències de les que hem fet esment en aquest treball i provar d'aplicar-les o de fer-ne una de nova! Com us hem comentat, el professorat dels seminaris de formació que ja ha experimentat aquest tipus de materials a l'aula, malgrat els peròs que podem trobar, fa una valora- ció positiva del resultat i les petites seqüències que han dissenyat així ho demostren. Així doncs, des de les Terres de l'Ebre, ànim i endavant!

A través del nostre correu electrònic ens podeu fer arribar les vostres opinions.

mvidal5@xtec.cat

itena2@xtec.cat

\section{BIBLIOGRAFIA}

Donades les característiques del treball, la consulta bibliogràfica ha estat extensa i molt diversa. Us indiquem una mostra de la bibliografia completa que trobareu a la memòria de la llicència.

ALCÁZAR,A. I PIGRAU, T. (1996). Quaderns de treball i dossiers del professor del Museu de la Ciència. Barcelona. Edita: Fundació "la Caixa".

ASSOCIACIÓ "PETITS DÉBROUILLARDS" (2002). Experimentos fáciles y divertidos. Los secretos del agua. Madrid. Editorial SM saber.

BORRUT, J.M, CAMPS, J, MAIXÉ, J.M. L'atmosfera: aproximació a l'estudi de la Meteorologia. (1991). Barcelona. Quaderns experimentals. Departament d'Ensenyament. Generalitat de Catalunya.

CALVET, M., I ALTRES. L'aire Què és $i$ què fa? Col.lecció 12-16. Barcelona. (1996). Ciència Activa..

DIVERSOS AUTORS. (1993). Biosfera. Planeta viu. Barcelona: Enciclopèdia Catalana.

DIVERSOS AUTORS. (1996). Elements de la vida. Química Salters per al batxillerat. València: Reproval, SL.

DIVERSOS AUTORS (1991). Guia del museu. Fundació "La Caixa". Barcelona.

FARGAS, M., FONT, V. Mesura i magnituds. (1995). Barcelona. Edicions Castellnou.

GREEN, J. (1992). Aprende a ser un buen meteorólogo. Barcelona. Editorial Parramón.

GRAN ENCICLOPEDIA CATALANA(1988). Enciclopèdia Catalana, Barcelona.

GUIA de l'Agenda 21. (1992). Departament de Medi Ambient. Barcelona.

GUIA del Museu de la Ciència de Barcelona. Fundació "La Caixa".

L'ARC de Sant Martí: un estudi teòric i experimental. Col.lecció Premis Cirit a la Joventut núm. 12.

L'ENERGIA del vent. Èol fa de les seves. Departament d'Indústria, comerç i Turisme. Institut Català de l'Energia.

MANUAL de Meteorología. Tecnología y Sistemas Didácticos, S.A. Madrid. ENOSA. 
MARTORELL, EDUARD I RODRÍGUEZ, ALFRED. (1997). Meteorologia, 2n. Cicle. L'Hospitalet de Llobregat. Editorial Text.

NUFFIELD (1973). Ciencia combinada. Barcelona. Editorial Reverté.

ROCA, N. (2002). La ciència et parla de... El clima. Barcelona: Editorial Molino.

RODRÍGUEZ PICÓ, A. (1993).Observant el temps. Barcelona. Enciclopèdia Catalana.

VECCHIONE, G. (2002). Experimentos sencillos sobre el cielo i la tierra. Barcelona. Editorial Oniro.

\section{Enllaços interessants d'Internet}

I a continuació, una breu mostra de les adreces d'internet han estat consultades, en major o menor mesura, per a confeccionar aquest treball.

Alguna d'elles la vam consultar fa temps i és possible que la referència no funcioni. És el problema d'aquesta mena de "bibliografia virtual". Al treball hi teniu un llistat més complet.

- http://www.xtec.cat/edumet/

- http://es.geocities.com/cienciesterra/tema3/CTM A03 05.HTML

- www.educaplus.org/

- http://www.xtec.es/cdec/formacio/formacio.htm

- ram@meteored.com

- www.aula21.es

- www.EDU365.com

- www.educadormarista.com/PQEDISON/opticaexperimentos.htm

- www.geocities.com

- www.maloka.org

- www.meteosort.com

- www.quimica.unlp.edu.ar/pagciencia/experfis.ht $\underline{m}$

- www.trianguisdefisica.com

- www.xtec.cat/dsantama/meteo/pagines/dites.ht $\mathrm{m}$

- www.xtec.cat/aulanet

- www.xtec.es/edumet/

- http://ciencianet.com/

- www.educaplus.org/

\section{AGRAIMENTS}

A totes les persones que ens han donat suport durant el curs 2005-06, començant pels membres de la meua família.

I a partir

d'aquest moment, "tot està per fer i tot és possible". 